\title{
RESURVEY OF BORE HOLE AT DYE 3, SOUTH GREENLAND
}

\author{
By B. Lyle HANSEN
}

(Polar Ice Coring Office, University of Nebraska-Lincoln, Lincoln, Nebraska 68588-0640, U.S.A.)

and N.S. GUNDESTRUP

(Department of Glaciology, Geophysical Institute, University of Copenhagen, Haraldsgade 6, DK-2200 Copenhagen N, Denmark)

ABSTRACT. The $2037 \mathrm{~m}$ deep bore hole at Dye 3 in south Greenland was surveyed in 1981, 1983, 1985, and 1986. The directional surveys show the ice flow is planar with a surface velocity of $12.2 \mathrm{~m} /$ year at an azimuth of $060^{\circ}$, which agrees with surface velocity measured by navigation satellites. Measurements of hole diameter and inclination are highly correlated with dust content in the ice. The temperature measurements show strong convection in the hole fluid with a cell height of about $20 \mathrm{~m}$ and an amplitude of $0.1 \mathrm{~K}$. The calculated mean in-situ ice density is $921.3 \pm 1.5 \mathrm{~kg} / \mathrm{m}^{3}$. Due to ice deformation, the lowest $4 \mathrm{~m}$ of the hole were not accessible in 1985 and the lowest $180 \mathrm{~m}$ were not accessible in 1986

\section{INTRODUCTION}

The Dye 3 bore hole (lat. $65^{\circ} 11^{\prime} \mathrm{N}$., long. $43^{\circ} 49^{\prime} \mathrm{W}$., elevation $=2484 \mathrm{~m}$ ) in south Greenland was surveyed just before the end of the drilling in 1981. It was resurveyed in 1983 (Gundestrup and Hansen, 1984), 1985, and 1986. The 1981 survey measured inclinations but not azimuth. The 1983 survey reached bottom. The bottom $4 \mathrm{~m}$ and $180 \mathrm{~m}$ were inaccessible in 1985 and 1986, respectively. In these two years slant-hole depths were calibrated using the previously measured depths of irregularities in the diameter and inclination. The 1985 and 1986 true vertical depths are accurate to $1.5 \mathrm{~m}$ assuming constant surface elevation (Reeh and Gundestrup, 1985). The casing length was $67.1 \mathrm{~m}$ when installed in 1979 (Rand, 1980). In 1981, $0.9 \mathrm{~m}$ was removed. In 1982 the casing was extended to the surface by adding $13.7 \mathrm{~m}$. The casing was extended $2.3 \mathrm{~m}$ in 1983, 1985, and 1986 to a total casing length of $86.8 \mathrm{~m}$. In 1981,4001 of heavy liquid (perchlorethylene, PCE) was added to the bore hole to free the stuck drill. After the 1983 and 1986 surveys, 4161 of diesel fuel were added to keep the fluid pressure equal to the overburden pressure at the bottom of the bore hole. To keep this equilibrium, the fluid level is more than $100 \mathrm{~m}$ below the surface. This introduces an under-pressure of up to $8 \mathrm{bar}$ in the upper part of the bore hole which leads to significant hole constriction.

In this paper, all depth references are given as vertical depths. The total vertical depth of the bore hole is $2033.2 \mathrm{~m}$, the slant-hole depth in 1981 (which is the same as the depth used for the core logging) was $2037.63 \mathrm{~m}$ (Gundestrup and others, 1984; Gundestrup and Johnsen, 1985). The relation between 1981 slant-hole depth (SHD) and vertical depth (VD) is as follows:

$$
\text { if } \begin{aligned}
\mathrm{VD}< & 1200 \mathrm{~m} \text {, then } \\
\mathrm{SHD} & =\mathrm{VD}-0.013+2.63 \times 10^{-4} \times \mathrm{VD}- \\
& -5.88 \times 10^{-7} \times \mathrm{VD}^{2}+6.72 \times 10^{-10} \times \mathrm{VD}^{3},
\end{aligned}
$$

if $\mathrm{VD}>1200 \mathrm{~m}$, then

$$
\begin{aligned}
\mathrm{SHD} & =\mathrm{VD}+7.859-0.0179 \times \mathrm{VD}+ \\
& +1.266 \times 10^{-5} \times \mathrm{VD}^{2}-2.31 \times 10^{-9} \times \mathrm{VD}^{3} .
\end{aligned}
$$

\section{EQUIPMENT}

The equipment used in 1981 and 1983 was described by Gundestrup and Hansen (1984). The first logging device used in 1985 was the University of Copenhagen (UCPH) unit which measures inclination, azimuth, fluid pressure, temperature, and diameter. Some changes were made to the 1983 configuration. A fluxgate compass was used instead of the Aanderaa-type 1248 magnetic compass. A temperatureprobe array was added to detect thermal convection in the bore-hole fluid. The thermistor electronics were modified to ensure a noise level significantly less than the resolution of the thermometer $(0.009 \mathrm{~K})$ without any smoothing. The UCPH serial numbers of the thermistors are: in 1980, No. $76-10$; in 1982, No. 76-10; in 1983, No. 83-4; in 1985, No. $83-2$; in 1986, No. 83-4. The resolution of the pressure transducer was increased to $15 \mathrm{~cm}$. The transducer (Paroscientific type $75 \mathrm{k}-002$ ) has been calibrated at $-50^{\circ}$, $-27^{\circ},-1^{\circ}$, and $+18^{\circ} \mathrm{C}$ by the Danish National Testing Board, traceable to PTB, Braunschweig 1984. The calibration indicated the following error characteristics for the transducer: hysteresis $64 \mathrm{mbar}$; $2 \mathrm{~K}$ uncertainty in temperature introduces a pressure error of $60 \mathrm{mbar}$; and a maximum scale error of $0.03 \%$. At the bottom, this corresponds to an estimated error of $150 \mathrm{mbar}$, which is equivalent to $1.5 \mathrm{~m}$ of depth. The sampling interval was reduced from 4 to $3 \mathrm{~s}$. The tool was lowered into and retrieved from the bore hole by the UCPH winch built specially for that purpose. The winch carries $3500 \mathrm{~m}$ of Rochester-type $1 \mathrm{H}-125 \mathrm{~K}$ double-armored, Tefzel insulated single-conductor cable. The cable has a diameter of $3.12 \mathrm{~mm}$. The winch has a speed range of 0 to $\pm 50 \mathrm{~cm} / \mathrm{s}$ and a lifting capacity of $200 \mathrm{~kg}$. A depth counter is interfaced to the console, making it possible to add the slant-hole depth to the logger's data stream.

The second logging device used in 1985 was the Polar Ice Coring Office (PICO) survey tool which measures inclination, azimuth, and temperature. The configuration is the same as that used in 1983. The Gearhart-Owen 800 SUA winch used for all surveys in 1983 was used with the PICO tool in 1985.

For the 1986 surveys, the UCPH equipment was identical to that used in 1985. The PICO survey tool was modified to include a battery-powered microprocessor. The microprocessor-controlled data-acquisition package (DAP) transmits the information to a standard computer terminal at the surface. The inclination and azimuth sensors were those used in the previous surveys. 


\section{MEASUREMENTS}

\section{Hole-liquid density}

Fluid density was calculated from measurements of depths and the pressure at that depth. The density profiles (Fig. 1) for 1985 and 1986 showed a significant decrease from the 1983 profile in the upper few hundred meters due to the addition of the light-density $\left(\approx 850 \mathrm{~kg} / \mathrm{m}^{3}\right)$ diesel fuel in 1983. There is a slight increase in fluid density in the bottom $200 \mathrm{~m}$ of the hole. The 1986 survey did not include that part of the hole.

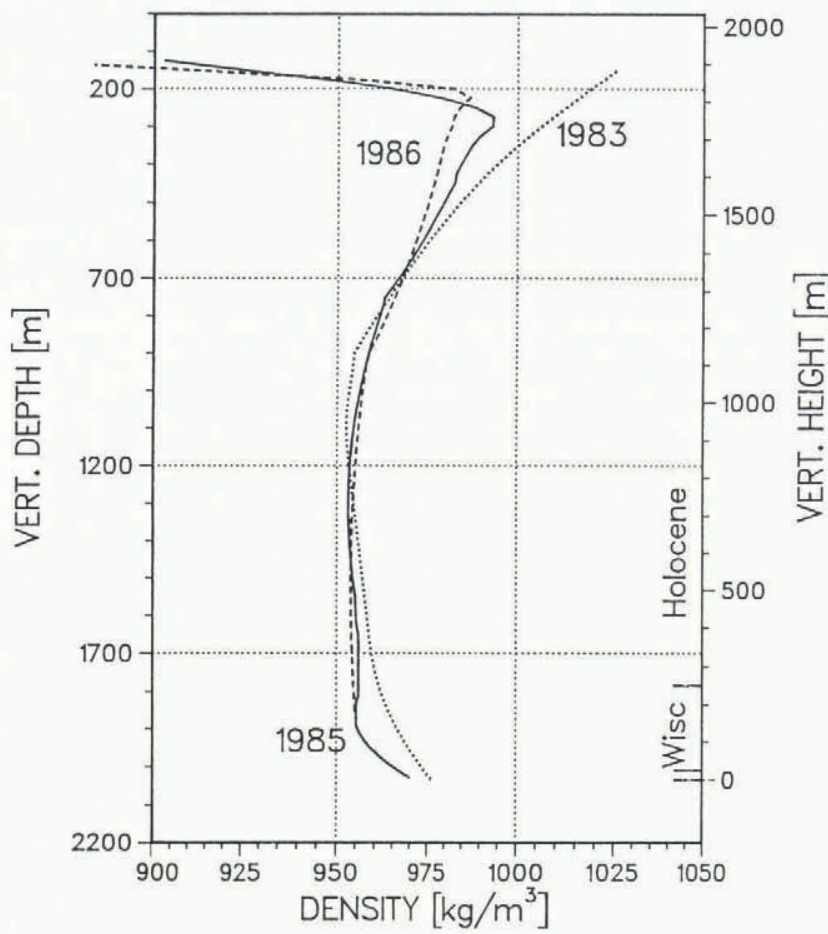

Fig. 1. Density of the liquid in the hole versus true vertical depth as measured in 1983, 1985, and 1986. The light liquid added after the 1983 season is clearly seen in 1985 and 1986.

\section{Diameter}

The diameter of the bore hole will decrease if the fluid pressure is less than the overburden pressure of the ice, and will increase if the fluid exceeds the overburden pressure.

The Wisconsin ice in the bottom $250 \mathrm{~m}$ of the hole deforms three to four times more readily than the Holocene ice above that level, and the silty ice in the lowest $25 \mathrm{~m}$ of the hole deforms an order of magnitude more readily than the Holocene ice.

The deliberate addition of 4001 of heavy fluid in 1981 , in a successful attempt to expand the diameter at the bottom of the hole to free the drill stuck there, increased the hole fluid density so that a shorter liquid column is needed to match the overburden ice pressure at the bottom. This created large under-pressure in the upper part of the bore hole.

Figure 2 shows the measured diameters in 1983, 1985, and 1986. There is pronounced hole closure in the upper $700 \mathrm{~m}$. The spikes at $800-900 \mathrm{~m}$ and at $1050 \mathrm{~m}$ are due to slippage of the anti-torque springs during drilling.

Figure 3 is an expanded view of the hole diameter versus depth in the lower part of the bore hole. The original diameter of the hole was $130.0 \mathrm{~mm}$ (Gundestrup and others, 1984). The diameter increase in the period 1981-83 shows that the fluid pressure exceeded the overburden pressure. The diameter decrease in 1985 and 1986 shows that the fluid pressure was less than the overburden pressure, except at the bottom of the hole where the 1985 diameter shows that the pressures were very nearly equal. In 1985 , both the UCPH and the PICO tools were unable to penetrate the lower $4 \mathrm{~m}$ of the bore hole. This possibility was foreseen and commented on in the 1983 survey

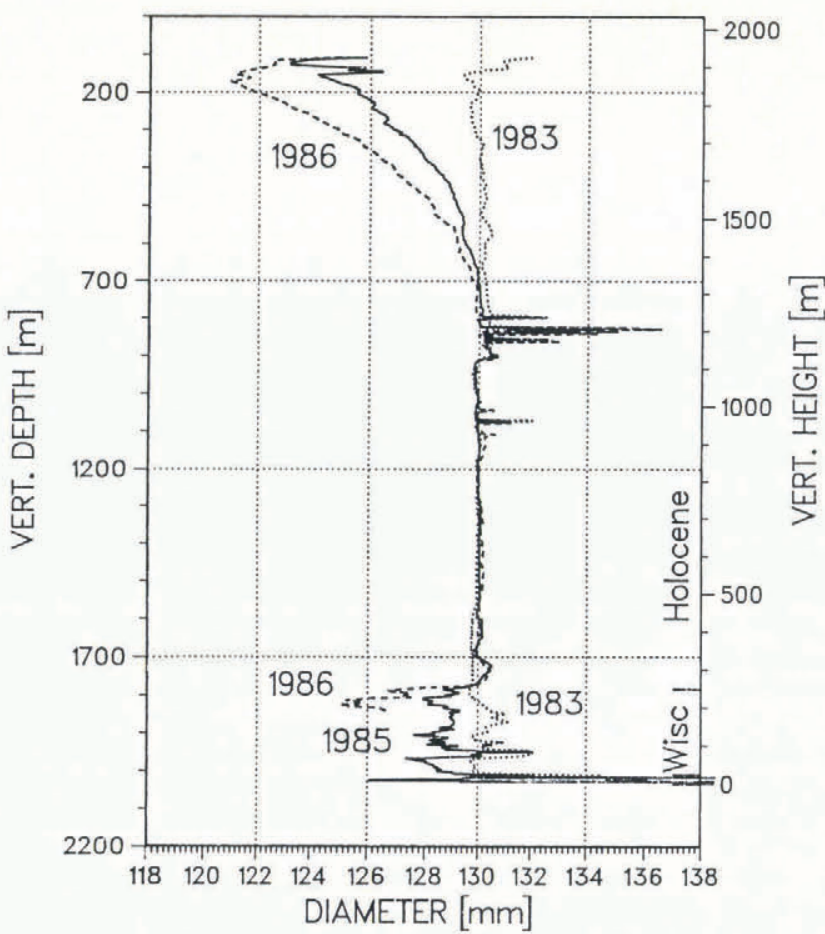

Fig. 2. Hole diameter versus vertical depth in 1983, 1985 , and 1986. The profiles are slightly smoothed. The upper $900 \mathrm{~m}$ was originally $130.5 \mathrm{~mm}$; below $900 \mathrm{~m}$, the diameter was $130.0 \mathrm{~mm}$.

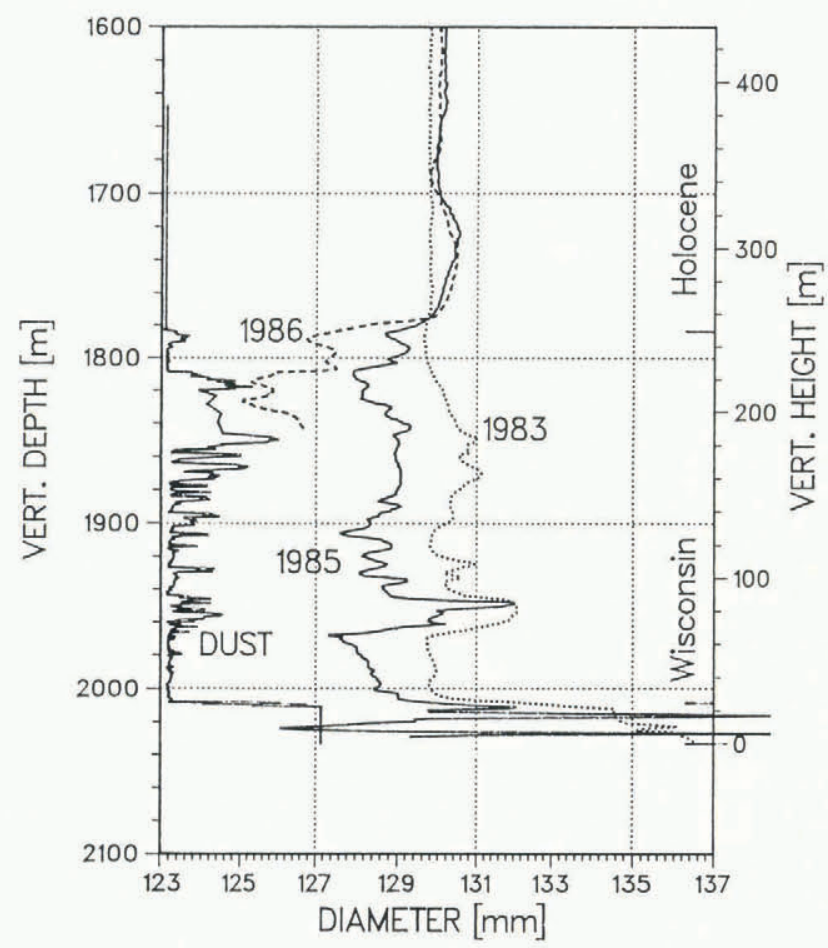

Fig. 3. Lowest part of Figure 2 shown expanded. The curve at the left is a dust index. The 1985 profile stops $4 \mathrm{~m}$ above the bottom of the hole. The 1986 profile stops at the highest dust peak in the Wisconsin.

(Gundestrup and Hansen, 1984).

In 1986, neither tool penetrated beyond a depth of $1850 \mathrm{~m}$. A very marked increase in inclination, correlated with a dust layer at that depth, probably explains the failure to lower the tools beyond that depth. As seen in Figure 3 , the penetration stopped at the highest dust peak in the Wisconsin. 
The change in diameter is highly correlated with the dust content, as is the case in the Agassiz Ice Cap A77 hole (Fisher and Koerner, 1986). At Law Dome, Antarctica, $c$-axis enhancement factors and bore-hole closures have been measured (Russell-Head and Budd, 1979; Thwaites and others, 1984; Budd and Rowden-Rich, 1985; Morgan and McCray, 1985). They observed high closure at depth intervals with large-grain and multiple-maxima ice. There are a number of differences between the Dye 3 and Law Dome situations that make comparison complicated. The overburden pressure $(\approx 20 \mathrm{bar})$ was higher at Law Dome than at Dye 3; the Law Dome ice contains less dust, the depth-shear relationship is more complicated at Law Dome, and Law Dome temperatures were close to the pressure melting-point.

\section{Ice density}

The hole pressure measured $2 \mathrm{~m}$ above the bottom of the hole in 1983 was 183.65 bar. In 1985, the absolute pressure $6 \mathrm{~m}$ above the bottom was 182.26 bar. Assuming that the 1985 fluid pressure is equal to the overburden pressure of the ice at that level, a density correction for the firn of $24 \mathrm{~m}$ (Clausen and others, 1988), a total vertical length of $2033.2 \mathrm{~m}$, a surface barometric pressure of $0.74 \mathrm{bar}$, acceleration of gravity $9.823 \mathrm{~m} / \mathrm{s}^{2}$, and correcting for the $2.5 \mathrm{~m}$ rise in fluid due to the immersion of the cable and survey tool, the calculated mean in-situ ice density is $921.3 \pm 1.5 \mathrm{~kg} / \mathrm{m}^{3}$. The compressibility of ice, 12 $\times 10^{-6} /$ bar (Dorsey, 1940) accounts for $1 \mathrm{~kg} / \mathrm{m}^{3}$ of the mean in-situ density. The calculated density is slightly higher than the $917-920 \mathrm{~kg} / \mathrm{m}^{3}$ measured on the relaxed Byrd Station core (Gow, 1970) and the $920.3 \mathrm{~kg} / \mathrm{m}^{3}$ at $-20^{\circ} \mathrm{C}$ and $918.7 \mathrm{~kg} / \mathrm{m}^{3}$ at $-10^{\circ} \mathrm{C}$ measured on artificial ice (Hobbs, 1974).

\section{Temperature}

The 1985 and 1986 temperature profiles were measured with a thermistor probe centered in the bore hole beneath the survey tool. The tool was lowered at a uniform speed

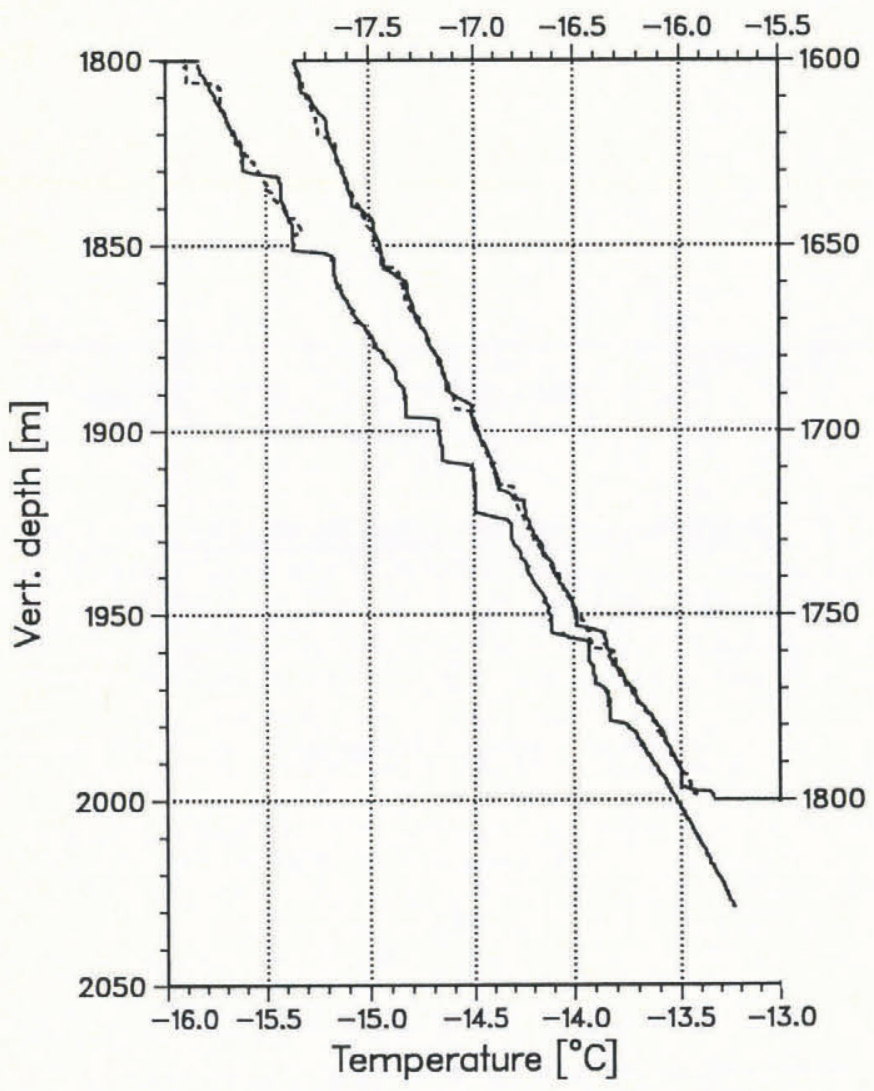

Fig. 4. Temperature below $1600 \mathrm{~m}$ in the center of the bore hole. The full line is the 1985 measurement; dashed line is 1986 measurements. The profiles show distinct convection in the hole liquid, except for below a depth of $1980 \mathrm{~m}$ where the liquid density increases. of approximately $40 \mathrm{~cm} / \mathrm{s}$. The overall profile is identical to that shown by Gundestrup and Hansen (1984) for the hole wall. The temperature profile below $1600 \mathrm{~m}$ is shown expanded in Figure 4. Convective circulation of the fluid is evident. The amplitude of the temperature fluctuations is larger in 1985 than in the 1986 profile (dashed line). Gundestrup and Hansen (1984) stated that convective circulation would be consistent with the physical and thermal properties of the bore-hole fluid and the temperature gradient of $12 \times 10^{-3} \mathrm{~K} / \mathrm{m}$ in the depth interval shown. The reduced amplitude in 1986 may be due to the presence of a block of ice being pushed down-hole by the probe. The convection cells are about $20 \mathrm{~m}$ long with a temperature step between cells of $0.1 \mathrm{~K}$. This change in temperature occurs over a depth range of less than $0.5 \mathrm{~m}$. Similar convection cells were observed in the $340 \mathrm{~m}$ fluidfilled Agassiz Ice Cap bore hole (Fisher, unpublished).

\section{DIRECTIONAL SURVEY}

Directional surveys of the Dye 3 bore hole were made in 1983, 1985, and 1986. The inclination of the bore hole over the entire depth is shown in Figure 5. This figure includes the 1981 data from the inclinometers mounted

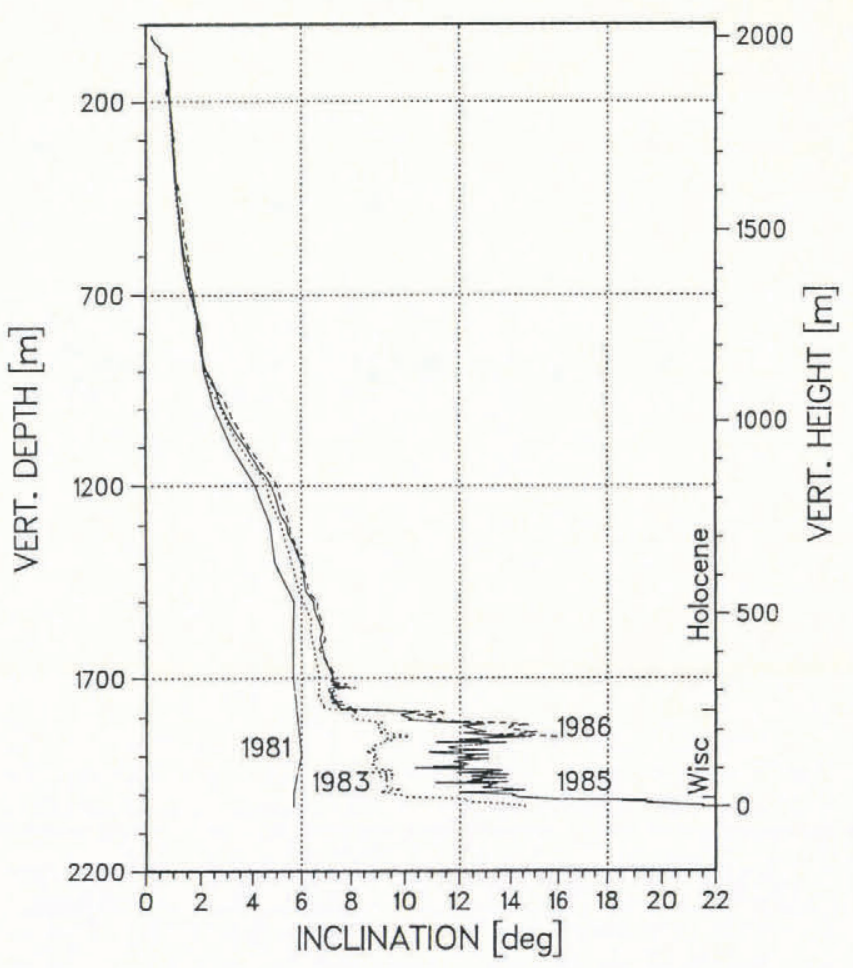

Fig. 5. Inclination versus vertical depth in 1981, 1983 , 1985 , and 1986.

inside the drill, and it is obvious that those readings are slightly too low. This possibility was discussed earlier (Gundestrup and Hansen, 1984). Figure 6 is an expanded view of the lower part of the inclination profiles compared with a dust profile at the left. The marked increase in deformation in the Wisconsin ice and in the silty ice below it is shown by the 1983 and 1985 surveys.

The azimuth of the bore hole over the entire depth is shown in Figure 7. The azimuth is essentially constant down to the Wisconsin ice, where significant changes are evident.

The velocity profile computed from the 1981, 1983 , 1985, and 1986 directional surveys is shown in Figure 8. It was computed using seven sets of measurements (DahlJensen and Gundestrup, 1987). The azimuth calculations show that the ice flow is unidirectional within the accuracy of the measurements $\left( \pm 5^{\circ}\right)$. The calculated surface velocity (assuming zero at the bottom) is $12.2 \mathrm{~m} /$ year at an azimuth of $060^{\circ}$. This is consistent with the results of the navigation-satellite position determinations. Mock (1976) 


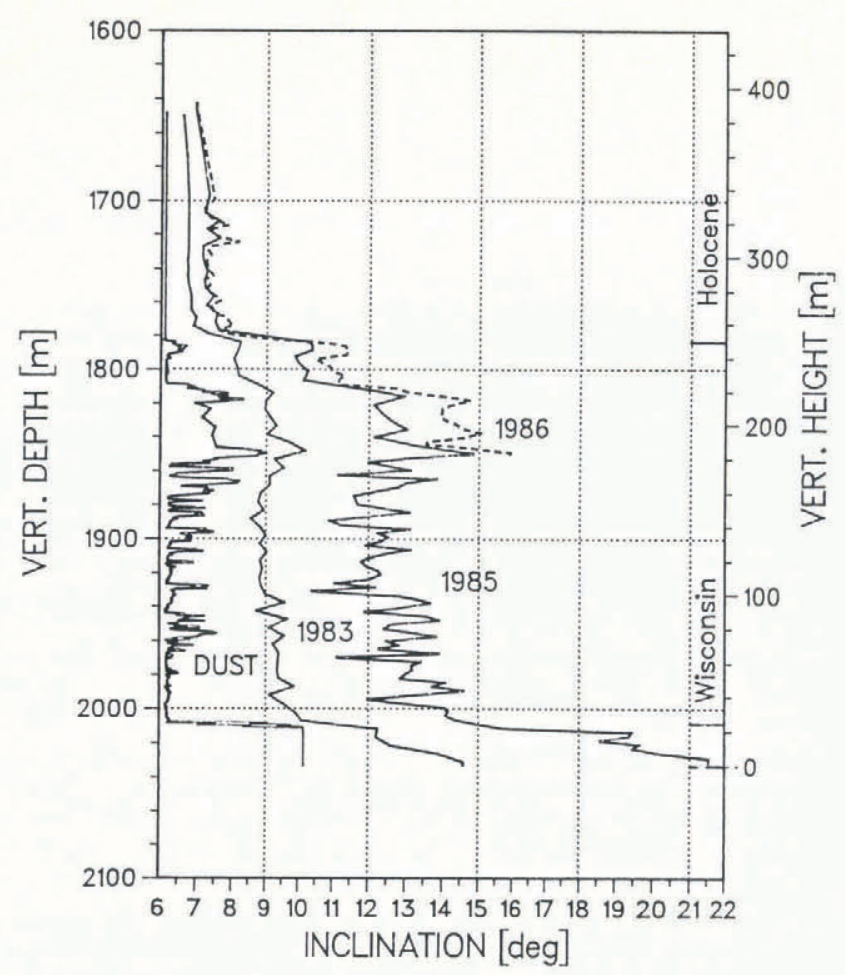

Fig. 6. Inclination versus vertical depth for depth below $1600 \mathrm{~m}$. The curve to the left is a dust index. These curves indicate a high correlation between tilting rate and dust content.

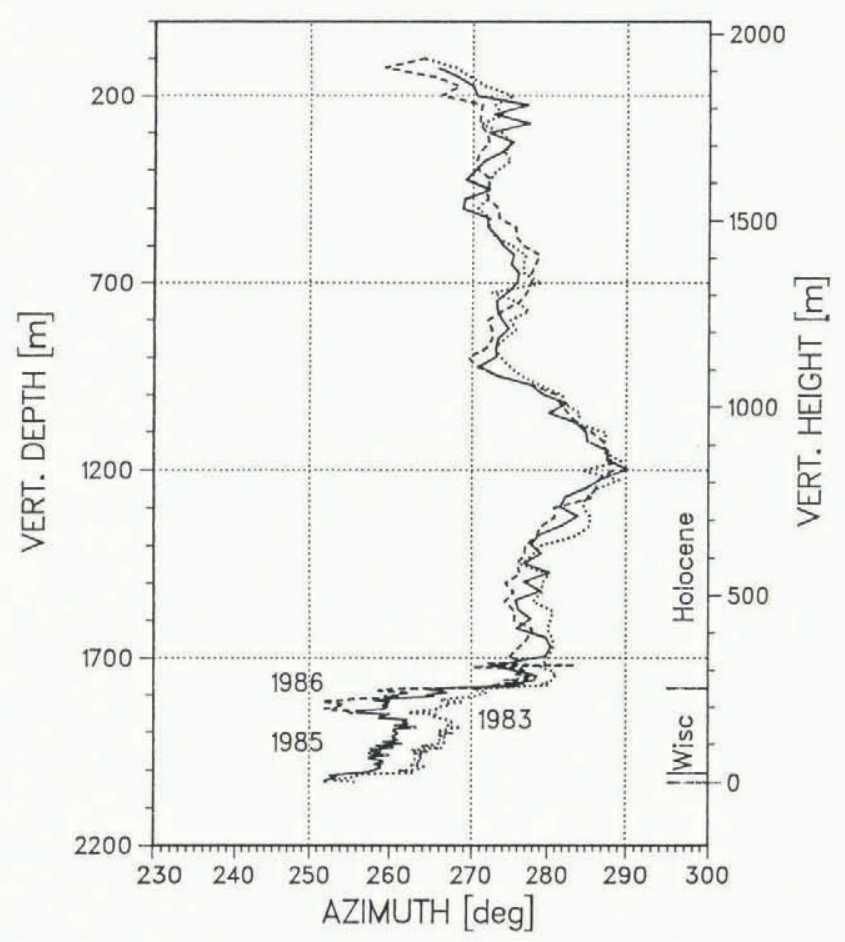

Fig. 7. Azimuth versus vertical depth in 1983, 1985, and 1986. There is very little change with time for Holocene ice. For Wisconsin ice, the azimuth goes towards $240^{\circ}$.

established in 1972 a station $450 \mathrm{~m}$ from the drill site. The position of the antenna at this station has been measured by satellite several times (Table I).

This table is an extension of that provided by Reeh and Gundestrup (1985). The antenna height over the WGS-72 ellipsoid is $2528.4 \pm 1.3 \mathrm{~m}$. With an antenna height over the surface of $1 \mathrm{~m}$, and a geoid height of $43.4 \mathrm{~m}$ (Rapp, 1978), the surface elevation is $2484 \pm 2 \mathrm{~m}$ above mean sea-level.

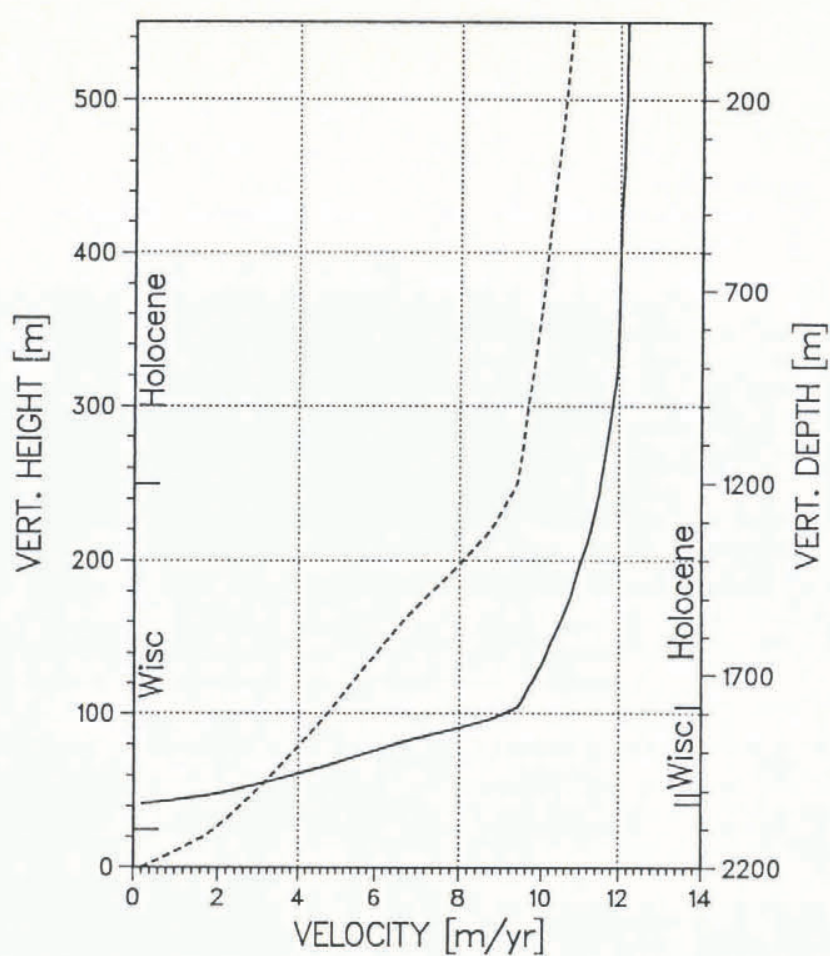

Fig. 8. Horizontal velocity versus vertical depth based on seven surveys in the period 1981-86.

TABLE I. POSITIONS OF MOCK STATION 1 IN WGS-72 COORDINATES

Year

$$
\stackrel{\text { Lat. }}{\stackrel{2}{\mathrm{~N}} \text {. }}
$$

Long.

Elevation

.586

65.187391

E.

$\mathrm{m}$

80.626

65.187814

316.169520

2526.76

81.548

65.187878

316.171377

2526.45

83.422

65.187977

316.171618

2529.68

85.479

65.188092

316.172051

2529.36

86.408

65.188139

316.172560

2529.21

2528.72

A linear fit to these data gives the velocity: $V_{1}=12.56 \pm 0.06 \mathrm{~m} /$ year, azimuth $061.2^{\circ} \pm 0.3^{\circ}$.

This velocity must be corrected for the local strain when moving the velocity to the drill site. This correction is $10 \mathrm{~cm} /$ year. Thus, the corrected velocity $\left(V_{\mathrm{d}}\right)$ at the drill site is:

$$
V_{\mathrm{d}}=12.6 \pm 0.1 \mathrm{~m} / \text { year, azimuth } 061.2^{\circ} \pm 0.5^{\circ} .
$$

This compares favorably with the independent result from the directional surveys.

The velocity profile (Fig. 8) is similar to the preliminary profile (Gundestrup and Hansen, 1984), which was based on lower-resolution inclinometer data. The higherresolution data from recent surveys show that the deformation in the upper half of the hole is smaller than the preliminary estimate. This was foreseen by Gundestrup and Hansen (1984).

\section{SUMMARY AND CONCLUSIONS}

Results from the 1985 and 1986 resurveys of the bore hole at Dye 3 have confirmed and refined the preliminary results based on the 1981 and 1983 surveys.

The convective circulation of the hole fluid which was anticipated in 1983 was observed in the 1985 and 1986 surveys. 
The diameter measurements have been disturbed by the changing fluid pressure in the bore hole. The addition of heavy liquid in 1981 made rapid closure of the upper parts of the bore hole unavoidable. It will be necessary to ream the $100-300 \mathrm{~m}$ depth interval in future years. The measurements in the Wisconsin ice and in the underlying silty ice show that the most rapid diameter increases (in 1983) and decreases (in 1985 and 1986) correlate with the layers with high dust content and high shear deformation rates.

The major features of the estimated velocity profile based upon the 1981 and 1983 surveys (Gundestrup and Hansen, 1984) are confirmed. The standard deviation of shear deformation rates is halved. The Wisconsin ice deforms more readily than the Holocene ice and there is a high correlation between dust content and shear deformation rate. This is in agreement with results from Canadian ice caps (Fisher and Koerner, 1986, 1987).

Future directional surveys in the upper $1800 \mathrm{~m}$ of the bore hole are needed to provide data for shear deformation rates in the Holocene ice. The differences between the 1983 and 1986 surveys are too small to do this for the upper $1200 \mathrm{~m}$. This depth interval, where only a few per cent of the deformation occurs, is of great value for the determination of flow properties.

\section{ACKNOWLEDGEMENTS}

We thank the PICO field operations managers S. Watson and K. Swanson for their logistical support. J.R. Kelty designed the PICO DAP and wrote the software for it. B. Farleigh made the electronic package in the PICO tool, and participated together with L. Riishøjgård in the 1986 field operation. This work has been sponsored by the U.S. National Science Foundation Division of Polar Programs under contract DPP83-18538, the University of Copenhagen, the Danish Commission for Scientific Research in Greenland, and the Commission of the European Communities under contract CLI.067.DK.

\section{REFERENCES}

Budd, W.F., and Rowden-Rich, R.J.M. 1985. Finite element analysis of two-dimensional longitudinal section flow on Law Dome. ANARE Research Notes, 28, 153-61.

Clausen, H.B., Gundestrup, N.S., Johnsen, S.J., Bindschadler, R.A., and Zwally, H.J. 1988. Glaciological investigations in the Crête area, central Greenland: a search for a new deep-drilling site. Annals of Glaciology, 10, $10-15$.

Dahl-Jensen, D., and Gundestrup, N.S. 1987. Constitutive properties of ice at Dye 3, Greenland. International Association of Hydrological Sciences Publication 170 (IUGG General Assembly of Vancouver 1987), 31-43.

Dorsey, N.E. 1940. Properties of ordinary water-substance in all its phases: water-vapor, water, and all the ices.
New York, Reinhold Publishing Corporation. (American Chemical Society Monograph Series 81.)

Fisher, D.A. Unpublished. Mer de Glace thermal anomalies. Ottawa, Polar Continental Shelf Project EMR. (Internal Report.)

Fisher, D.A., and Koerner, R.M. 1986. On the special rheological properties of ancient microparticle-laden Northern Hemisphere ice as derived from bore-hole and core measurements. Journal of Glaciology, 32(112), 501- 10 .

Fisher, D.A., and Koerner, R.M. 1987. Enhanced flow of Wisconsin ice related to solid conductivity through strain history and recrystallization. International Association of Hydrological Publication 170 (IUGG General Assembly of Vancouver 1987), 45-51.

Gow, A.J. 1970. Preliminary results of studies of ice cores from the $2164 \mathrm{~m}$ deep drill hole, Byrd Station, Antarctica. International Association of Scientific Hydrology Publication 86 (ISAGE), 78-90.

Gundestrup, N.S., and Hansen, B.L. 1984. Bore-hole survey at Dye 3, south Greenland. Journal of Glaciology, $30(106), 282-88$

Gundestrup, N.S., and Johnsen, S.J. 1985. A battery powered, instrumented deep ice core drill for liquid filled holes. In Langway, C.C., jr, Oeschger, H., and Dansgaard, W., eds. Greenland ice core: geophysics, geochemistry, and the environment. Washington, DC, American Geophysical Union, 19-22. (Geophysical Monograph 33.)

Gundestrup, N.S., Johnsen, S.J., and Reeh, N. 1984. ISTUK; a deep ice core drill system. CRREL Special Report, 84-34, 7-19.

Hobbs, P.V. 1974. Ice physics. Oxford, etc., Clarendon Press.

Mock, S. 1976. Geodetic positions of bore-hole sites of the Greenland Ice Sheet Program. CRREL Special Report, 76-41.

Morgan, V.I., and McCray, A.P. 1985. Enhanced shear zones in ice flow - implications for ice cap modelling and core dating. ANARE Research Notes, 28, 4-9.

Rand, J. 1980. 1979 Greenland Ice Sheet Program. Phase 1: casing operation. CRREL Special Report, 80-24.

Rapp, R.H. 1978. A global 1 deg. $\times 1$ deg. anomaly field combining satellite, Geos-3 altimeter and terrestrial data. Columbus, $\mathrm{OH}$, Ohio State University. Department of Geodetic Science. (Report 278.)

Reeh, N., and Gundestrup, N.S. 1985. Mass balance of the Greenland ice sheet at Dye 3. Journal of Glaciology, 31(108), 198-200.

Russell-Head, D.S., and Budd, W.F. 1979. Ice-sheet flow properties derived from bore-hole shear measurements combined with ice-core studies. Journal of Glaciology, 24(90), 117-30.

Thwaites, R.J., Wilson, C.J.L., and McCray, A.P. 1984. Relationship between bore-hole closure and crystal fabrics in Antarctic ice core from Cape Folger. Journal of Glaciology, 30(105), 171-79. 